\title{
Expression of neural stem cell markers in malignant rhabdoid tumor cell lines
}

\author{
KAZUTO OKUNO $^{1}$, SHIGERU OHTA ${ }^{1}$, HIROFUMI KATO ${ }^{1}$, \\ TAKASHI TAGA $^{1}$, KANJI SUGITA ${ }^{2}$ and YOSHIHIRO TAKEUCHI ${ }^{1}$ \\ ${ }^{1}$ Department of Pediatrics, Shiga University of Medical Science, Tsukinowa, Otsu, Shiga 520-2192; \\ ${ }^{2}$ Department of Pediatrics, School of Medicine, University of Yamanashi, 1110 Shimokato, \\ Chuo, Yamanashi 409-3898, Japan
}

Received August 4, 2009; Accepted October 16, 2009

DOI: 10.3892/or_00000659

\begin{abstract}
Malignant rhabdoid tumor (MRT) is considered to display multi-phenotypic characteristics but the true origin of this tumor remains unknown. In recent years, the concept of the cancer stem cell (CSC) has drawn great attention. In the present study we investigated six MRT cell lines (TM87-16, STM91-01, TTC642, TTC549, YAM-RTK-1 and TTC1240), for CD133, nestin and Musashi-1 (Msi-1), which are considered to be CSC as well as neural stem cell (NSC) markers, using assays for cell viability and apoptosis, reverse transcriptional polymerase chain reaction (RT-PCR), semiquantitative PCR and Western blot analysis before and after differentiation-induction with $\mathrm{N}$-(4-hydroxyphenyl) retinamid (4-HPR). Before differentiation-induction with 4-HPR, CD133 was detected in three MRT cell lines, nestin in three cell lines and Msi-1 in five cell lines. In TTC549 after differentiation-induction with 4-HPR, nestin and Msi-1 were down-regulated in a time-dependent manner. Similar downregulation of Msi-1 was recognized in YAM-RTK-1. In STM91-01, CD133 was gradually down-regulated and Msi-1 was down-regulated after a transient increase. Results from our study indicated that 4-HPR might be effective in some MRTs. Expression of NSC markers showed that some MRTs contain a subpopulation of NSC and down-regulation of NSC markers in MRT cells provides supportive evidence that many MRTs could be considered of neuroectodermal origin.
\end{abstract}

\section{Introduction}

Malignant rhabdoid tumor (MRT) was first described in the kidney as a rare variant of Wilms' tumor with rhabdomyosarcomatoid features. Due to its high potential for metastasis,

Correspondence to: Dr Shigeru Ohta, Department of Pediatrics, Shiga University of Medical Science, Tsukinowa, Otsu, Shiga 520-2192, Japan

E-mail: ohta@belle.shiga-med.ac.jp

Key words: malignant rhabdoid tumor, neural stem cell, cancer stem cell, differentiation-induction, $\mathrm{N}$-(4-hydroxyphenyl) retinamid, CD133, nestin, musashi-1
MRT has an extremely poor prognosis (1). Primary MRT also has been described in the central nervous system (CNS), paravertebral regions, pelvis, liver, orbit and ovary as well as the kidney (2-7). A characteristic feature of MRT cells is the presence of large cytoplasmic eosinophilic inclusions $(8,9)$. In the brain, the tumors may present as a mixture of rhabdoid, primitive neuroectodermal, mesenchymal and/or epithelial elements, an entity referred to as atypical teratoid/rhabdoid tumors $(10,11)$.

The phenotypic diversity of MRT cells has been reported, but the histological origin of MRT still remains unclear. Various cellular origins of MRT, such as neuroectodermal $(8,9,12)$, neural $(13-15)$, epithelial (16), histiocytic (17) or myogenic (18), have been proposed. Despite the variability observed in tumor location and histology, most rhabdoid tumors share a similar genetic origin and are characterized by the presence of mutations in the hSNF5/INI1 gene on chromosome band 22q11.2 (19-21). Approximately $70 \%$ of primary tumors carry mutations and/or deletions in both copies of the hSNF5/INI1 gene, whereas an additional 20 to $25 \%$ of tumors have reduced expression at the RNA or protein level, indicating that loss-of-function of the INI1 protein is a central event in the development of MRT (19).

The concept of the CSC arose from the observation of striking similarities between the self-renewal mechanisms of stem cells and cancer cells $(22,23)$. Since normal somatic stem cells must self-renew and maintain a relative balance between self-renewal and cellular differentiation, cancer stem cells can be contextualized as a disease of un-regulated self-renewal (22). In recent years, the concept of CSC involvement in tumorigenesis has attracted the attention of many researchers. Previous studies have shown that NSC acting as CSC is recognized in CNS (24-29). In the present study, we examined the expression of NSC markers such as CD133, nestin and Msi-1 before and after 4-HPR induced differentiation in MRT cell lines to elucidate the cytological characteristics of MRT cells that are considered to derive from neuroectodermal origin $(8,9,12)$.

\section{Materials and methods}

Cell culture and differentiation. The MRT cell lines used in this study (TM87-16, STM91-01, TTC642, TTC549 and 
TTC1240) were provided by Dr Hiroyuki Shimada and Dr Timothy J. Triche (Childrens Hospital Los Angeles, CA, USA). The MRT cell line YAM-RTK1 was provided by Dr Kanji Sugita (Yamanashi University, Kofu, Japan). Diagnosis of these MRT cell lines was based on the presence of a large eosinophilic cytoplasmic inclusion by light microscopy and it was recently reported that these cell lines have homozygous deletion (TM87-16, STM91-01, TTC549, YAM-RTK1) or point mutations (TTC642, TTC1240) of the hSNF5/INI1 gene. Clinical data of the patients relevant to the establishment of the tumor-derived cell lines are summarized in Table I. Rhabdomyosarcoma cell line RMS-01, Ewing's sarcoma cell line ES-O-02, neuroblastoma cell line NB-01 and acute myeloid leukemia (AML) cell line AML-01 were established from primary tumors in our laboratory. The MRT and other cell lines used in this study were isolated from the 16th through 23rd passages. Tumorigenesis of these cell lines was confirmed by injection into nude mice (data not shown). At $37^{\circ} \mathrm{C}$ in a humidified incubator with $5 \% \mathrm{CO}_{2}$, the cells were cultured in RPMI-1640 (Invitrogen, Carlsbad, CA, USA) supplemented with $10 \%$ fetal bovine serum (FBS) (ICN Biomedicals, Inc., Aurora, OH, USA) and 1\% AntibioticAntimycotic Stabilized (Sigma, St. Louis, MO, USA). 4HPR (Sigma), also known as fenretinide, is a synthetic derivative of all-trans retinoic acid (ATRA) and is less toxic and substantially less teratogenic than ATRA (30). The compounds were dissolved in absolute ethanol at a concentration of $10 \mathrm{mM}$ and stored at $-20^{\circ} \mathrm{C}$. To induce differentiation, cells were treated with 4 -HPR for 2 to 8 consecutive days. The cell lines were analyzed for expression of CSC marker mRNAs and proteins before and after differentiation-induction with 4-HPR.

Cell viability assay. To investigate the effect of 4-HPR, cell viability was determined by Cell Counting Kit-8 (Dojindo Laboratories, Kumamoto, Japan) to count living cells by combining 2-(2-methoxy-4-nitrophenyl)-3-(4-nitrophenyl)-5(2,4-disulfophenyl)-2H-tetrazolium (WST-8) and 1-methoxyphenazine methosulfate (1-methoxy-PMS). Briefly, MRT cells were seeded into 96 -well plates at an initial density of 5,000 cells/well in $100 \mu \mathrm{l}$ medium and cultured in the presence of various concentrations $(1,3$ or $10 \mu \mathrm{M})$ of 4-HPR. After incubation with 4-HPR, $10 \mu \mathrm{l}$ of the kit reagent was added and incubated for $3 \mathrm{~h}$ at $37^{\circ} \mathrm{C}$. Cell viability was obtained by scanning with a microplate reader at $450 \mathrm{~nm}$.

Apoptosis assay. For exclusion of apoptosis with 4-HPR, genomic DNA with an exposure of $3 \mu \mathrm{M} 4$-HPR was extracted using a Suicide-Track ${ }^{\mathrm{TM}}$ DNA ladder isolation kit (Calbiochem, San Diego, CA, USA). Fragmented DNA was resolved on $1.5 \%$ agarose gels (Nakalai Tesque, Kyoto, Japan) visualized by $0.2 \mathrm{mg} / \mathrm{ml}$ ethidium bromide (EtBr; Nippon Gene, Tokyo, Japan) staining and examined under ultraviolet light.

$R N A$ preparation and RT-PCR. Total RNA from each cell line was extracted using a Fast-Pure RNA Kit (Takara Bio Inc., Otsu, Japan) according to the manufacturer's instructions. RNA concentrations of each sample were measured using a spectrophotometer (SmartSpec Plus; Bio-Rad, Hercules, CA,
USA). After adjusting the amounts of template RNAs, firststrand complimentary DNAs (cDNAs) were prepared by reverse transcription of total RNAs with Oligo dT primer using PrimeScript $^{\circledR}$ RT-PCR kit (Takara Bio Inc.).

PCR primers and conditions. To adjust the amount of transcribed cDNAs, glyceraldehyde-3-phosphate dehydrogenase (GAPDH) was selected as an internal control. All primer sequences are shown in Table II. All primers were designed with Primer 3 after sequence information was obtained from NCBI GenBank. The primary amplification of the specimen was performed in a final reaction volume of $50 \mu 1$. The reaction mixture contained $2.5 \mu 1$ of cDNA as template, $0.5 \mu \mathrm{M}$ each of the forward and reverse primers, $200 \mu \mathrm{M}$ of deoxynucleoside triphosphate mixture (dNTP, Takara Bio Inc.), 10X Ex Taq buffer (Takara Bio Inc.), 1.25 U Takara EX Taq ${ }^{\mathrm{TM}}$ HS (Takara Bio Inc.) and distilled water. All PCR amplifications were carried out using 2720 Thermal Cycler (Applied Biosystems, Carlsbad, CA, USA) for 30 cycles under the following conditions: denaturing at $94^{\circ} \mathrm{C}$ for $30 \mathrm{sec}$, annealing at different temperatures (see Table II) for $30 \mathrm{sec}$ and extension at $72^{\circ} \mathrm{C}$ for $60 \mathrm{sec}$.

PCR product sequencing. These PCR products were then purified using an illustra GFX PCR Purification kit (GE Healthcare, Buckinghamshire, UK) and were directly sequenced on both strands using an ABI Prism Big Dye Terminator v 1.1 Cycle Sequencing Kit (Applied Biosystems) and ABI PRISM 310 Genetic Analyzer 310 (Applied Biosystems).

Semi-quantitative PCR. Analyses were routinely performed with fixed quantities of target templates and three different quantities of competitor templates. Aliquots of the PCR $(10 \mu 1)$ were electrophoresed in $1.5 \%$ agarose gels containing $0.2 \mathrm{mg} /$ $\mathrm{ml}$ EtBr. The amount of DNA in each band was determined by quantifying the fluorescent intensity with AIC Epi-Light UV FA1100 (Aisin Cosmos R\&D, Tokyo, Japan) and the accompanying software program of Luminous Imager (Aisin Cosmos). The density of each band representing amplified product from sample and competitor was measured. The ratios of the densities (sample/competitor) were calculated and normalized relative to GAPDH.

Homogenate preparation. Cell suspension with $1 \mu \mathrm{M}$ aminobenzamide and $20 \mu \mathrm{M}$ phenylmethanesulfonyl fluoride was sonicated three times for $10 \mathrm{sec}$ by an Astrason ultrasonic processor XL with the pulsar dial 4-5 (Misonix, Inc., Farmingdale, NY, USA). A half volume of $4.4 \mathrm{mM}$ digitonin solution of the sonicated homogenate was added to the homogenate and the mixture was incubated for $30 \mathrm{~min}$ at $0^{\circ} \mathrm{C}$. Protein content was measured with a BCA protein assay kit (Pierce Chemical, Rockford, IL, USA).

Western blot analysis. Six MRT cell lines were examined by Western blot analysis for expression of CD133, nestin and Msi-1. The protein samples were subjected to 7.5 or $10 \%$ sodium dodecyl sulfate-polyacrylamide gel electrophoresis and transferred onto polyvinylidine difluoride (PDVF) membranes (Bio-Rad Laboratories). The membrane was 
Table I. Malignant rhabdoid tumor cell lines.

\begin{tabular}{lccllll}
\hline & Age (month) & Gender & Primary site & Outcome & Origin of cell line & hSNF5/INI1 gene \\
\hline TM87-16 & 21 & M & Retroperitoneal & Died & Pleural effusion & Homozygous deletion \\
STM91-01 & 8 & M & Left kidney & Died & Lung metastasis & Partial deletion \\
TTC642 & 5 & F & Neck mass & Died & Primary site & Nonsense mutation \\
TTC549 & 6 & F & Hepatic mass & Died & Primary site & Homozygous deletion \\
YAM-RTK-1 & 7 & M & Left kidney & Died & Ascites & Partial deletion \\
TTC1240 & 9 & F & Right kidney & Died & Brain tumor & Nonsense mutation \\
\hline
\end{tabular}

Table II. Primer sequences in the present study.

\begin{tabular}{|c|c|c|c|}
\hline Gene & Primer (5'-3') forward/reverse & Annealing temperature $\left({ }^{\circ} \mathrm{C}\right)$ & Product (bp) \\
\hline CD133 & $\begin{array}{l}\text { CTGGGGCTGCTGTTTATTATTCTG } \\
\text { ACGCCTTGTCCTTGGTAGTGTTG }\end{array}$ & 58 & 336 \\
\hline Nestin & $\begin{array}{l}\text { ACTGGAGTCTGTGGAAGTGA } \\
\text { TCAGCTCCCGCAGCAGACTCACC }\end{array}$ & 64 & 683 \\
\hline Musashi-1 & $\begin{array}{l}\text { CACGTTTGAGAGTGAGGACA } \\
\text { GGAATTCGGGGAACTGGTAG }\end{array}$ & 61 & 275 \\
\hline GAPDH & $\begin{array}{l}\text { GCCAAAAGGGTCATCATCTCTG } \\
\text { CATGCCAGTGAGCTTCCCGT }\end{array}$ & 55 & 348 \\
\hline
\end{tabular}

incubated for $4 \mathrm{~h}$ in blocking solution, $1 \mathrm{~h}$ in a solution of mouse anti-CD133/1 mAb (W6B3C1; Miltenyi Biotec Inc., Auburn, CA, USA), mouse anti-nestin mAb (MAB5326; Chemicon, Temecula, CA, USA), or mouse anti-Msi-1 mAb (MAB2628; R\&D Systems, Inc., Minneapolis, MN, USA) and $40 \mathrm{~min}$ in a solution of horseradish-peroxidase-conjugated secondary antibody. The detection solution was then added, the membrane was exposed to film for $5 \mathrm{~min}$ and the protein was visualized by ECL Plus Western blotting detection system (GE Healthcare).

\section{Results}

Cell viability assay. To analyze the toxicity of 4-HPR, MRT cell lines were cultured for $48-96 \mathrm{~h}$ with various concentrations of 4-HPR. Cell viability decreased slightly after $48 \mathrm{~h}$ incubation with $1 \mu \mathrm{M}$ 4-HPR in the four cell lines TM87-16, TTC642, TTC549 and YAM-RTK-1, while the MRT cell lines STM91-01 and TTC1240 were resistant to $96 \mathrm{~h}$ exposure of $1 \mu \mathrm{M}$ 4-HPR (Fig. 1). After incubation with $3 \mu \mathrm{M}$ 4-HPR, it was notable in TTC549 and YAM-RTK-1, though all MRT cell lines except TTC1240 showed a decrease in cell viability. Cell viability with $10 \mu \mathrm{M}$ 4-HPR was significantly decreased in all MRT cell lines. For further experiments, a dose of $3 \mu \mathrm{M}$ 4-HPR was considered to be appropriate to induce the cellular differentiation.

Apoptosis assay. Low concentrations of 4-HPR tend to induce neuronal cell differentiation (31), while high concentrations of 4-HPR induce apoptosis or necrosis (32). To assess that the decrease in cell viability in TTC549 and YAM-RTK-1 was not due to $3 \mu \mathrm{M}$ 4-HPR induced apoptosis, an apoptosis assay was investigated. Apoptosis was not detected in either cell line with 24 or $48 \mathrm{~h}$ exposure of $3 \mu \mathrm{M}$ 4-HPR (Fig. 2). Other MRT cell lines showed similar results.

Light microscopy. TTC549 cells showed a round morphology before differentiation-induction (Fig. 3A) and demonstrated the production of elongated cytoplasmic processes after differentiation-induction with $3 \mu \mathrm{M}$ 4-HPR (Fig. 3B). Though STM91-01 cells also showed a round appearance before differentiation-induction such as TTC549 (Fig. 3C), only mild epithelial changes were observed after differentiation-induction with $3 \mu \mathrm{M}$ 4-HPR (Fig. 3D). Other MRT cell lines showed no significant morphological changes after differentiationinduction with $3 \mu \mathrm{M}$ 4-HPR.

mRNA for NSC markers before 4-HPR treatment. CD133 mRNA was detected strongly in STM91-01 and weakly in TM87-16 and TTC1240 before treatment with 4-HPR (Fig. 4). Nestin mRNA expression was observed in STM91-01, TTC549 and TTC1240 (Fig. 4). Msi-1 mRNA was expressed in all MRT cell lines except TTC642 (Fig. 4).

Competitive RT-PCR of NSC markers before and after differentiation-induction with 4-HPR. TTC549 expressed nestin and Msi-1 mRNA before differentiation-induction with 4-HPR. Nestin and Msi-1 mRNA expression were downregulated in a time-dependent manner after differentiationinduction with $3 \mu \mathrm{M} 4-\mathrm{HPR}$ (Fig. 5A). Though the 

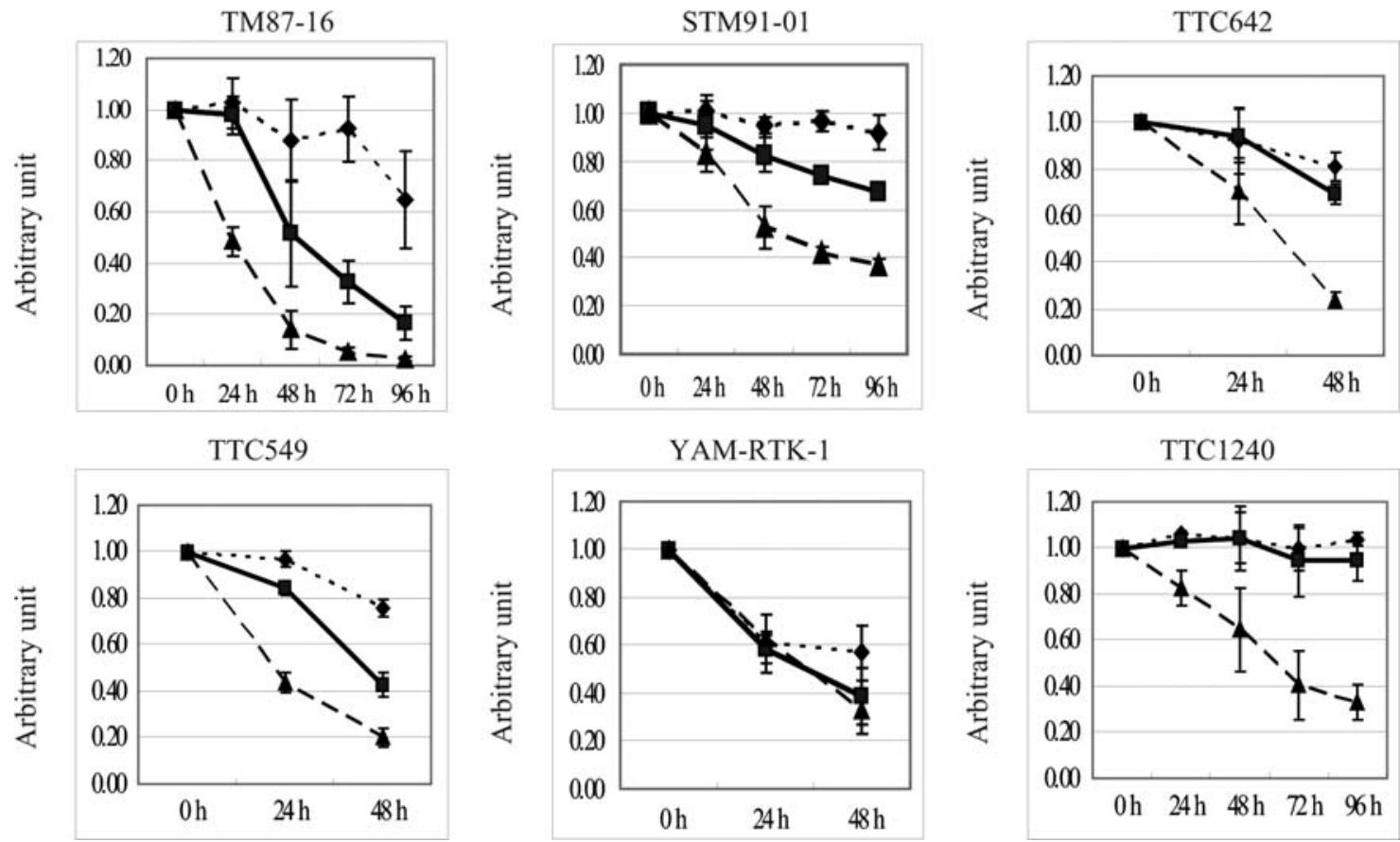

Figure 1. Cell viability assay of malignant rhabdoid tumor (MRT) cell lines cultured for 48-96 h with various concentrations of N-(4-hydroxyphenyl) retinamid (4-HPR). Diamonds represent the cell viability for differentiation-induction with $1 \mu \mathrm{M}$ 4-HPR, squares for differentiation-induction with $3 \mu \mathrm{M}$ 4-HPR, and triangles for differentiation-induction with $10 \mu \mathrm{M} 4$-HPR.

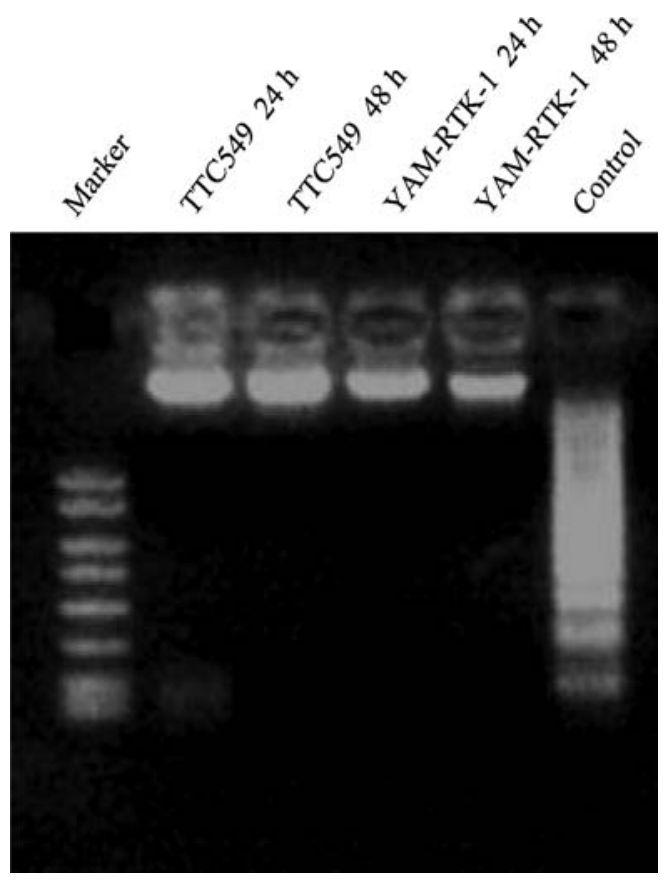

Figure 2. Apoptosis assay in malignant rhabdoid tumor (MRT) cell lines rules out that the decrease of cell viability in TTC549 and YAM-RTK-1 is not due to $3 \mu \mathrm{M} \mathrm{N}$-(4-hydroxyphenyl) retinamid (4-HPR) induced apoptosis. Apoptosis was not detected in either cell line with 24 or $48 \mathrm{~h}$ exposure of 3 $\mu \mathrm{M} 4-\mathrm{HPR}$.

morphological change was not remarkable by microscopic examination, Msi-1 mRNA expression in YAM-RTK-1 slightly decreased after differentiation-induction with $3 \mu \mathrm{M}$ 4-HPR (Fig. 5B). Interestingly, Msi-1 mRNA expression in STM91-01 was increased temporarily with the peak level at $96 \mathrm{~h}$ and decreased afterwards, while CD133 mRNA
A

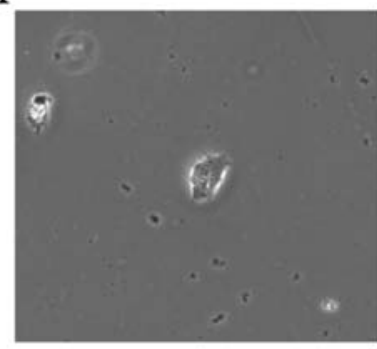

B

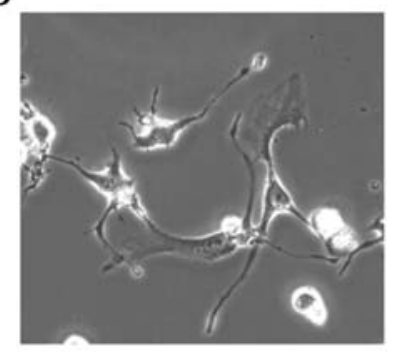

C

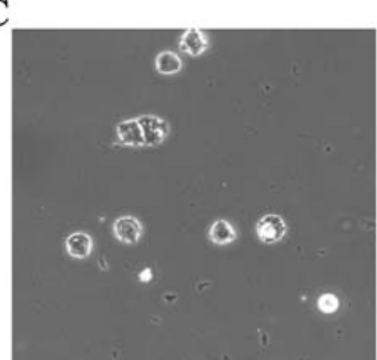

$\mathrm{D}$

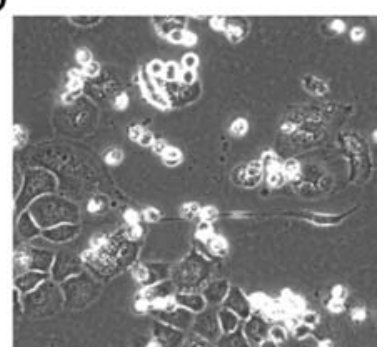

Figure 3. Light microscopic findings in malignant rhabdoid tumor (MRT) cells. (A) TTC549 cells showed a round morphology before differentiationinduction with $\mathrm{N}$-(4-hydroxyphenyl) retinamid (4-HPR). (B) After differentiation-induction with 4-HPR, TTC549 cells demonstrated the production of elongated cytoplasmic processes. (C) STM91-01 cells showed a round appearance before differentiation-induction with 4-HPR. (D) After differentiation-induction with 4-HPR, only mild epithelial changes were observed in STM91-01 cells.

expression decreased gradually in a time-dependent manner and nestin mRNA expression had no obvious change (Fig. 5C). In other MRT cell lines, CSC markers did not change significantly before and after differentiation-induction with 4-HPR. 


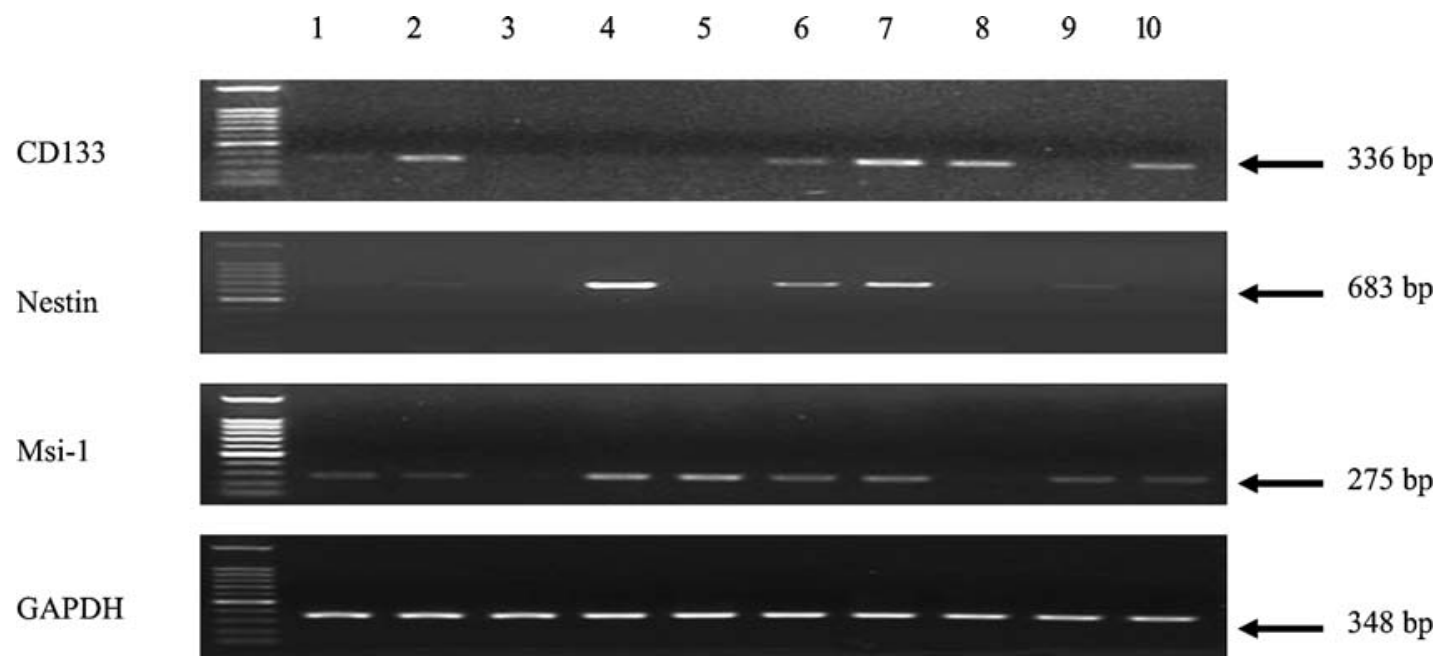

Figure 4. Results of expression of various neural stem cell markers in malignant rhabdoid tumor (MRT) and other cell lines using reverse transcriptional polymerase chain reaction (RT-PCR). CD133 mRNA was detected in three MRT cell lines (i.e. TM87-16, STM91-01 and TTC1240), RMS-01, ES-2-OT and AML-01. Nestin mRNA expression was observed in three MRT cell lines (i.e. STM91-01, TTC549 and TTC1240), RMS-01 and NB-01. Musashi-1 (Msi-1) mRNA was expressed in all MRT cell lines except TTC642. Msi-1 mRNA was also expressed in other cell lines (i.e. RMS-01, NB-01 and AML-01). Lane 1, TM87-16; lane 2, STM91-01; lane 3, TTC642; lane 4, TTC549; lane 5, YAM-RTK-1; lane 6, TTC1240; lane 7, RMS-01; lane 8, ES-2-OT; lane 9, NB-01; lane 10, AML-01.

A

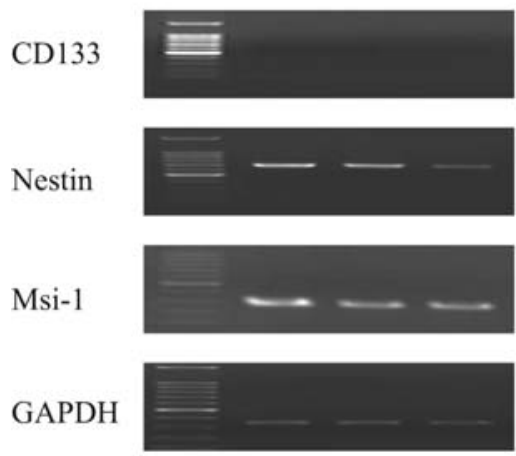

B
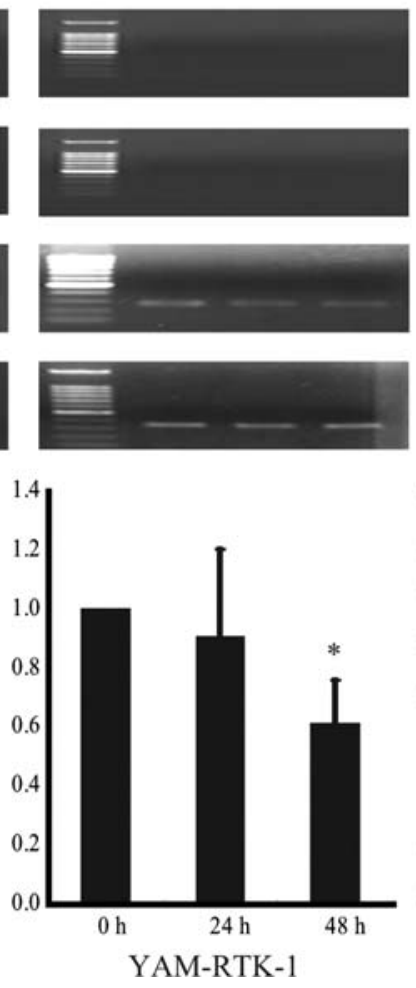

$\mathrm{C}$
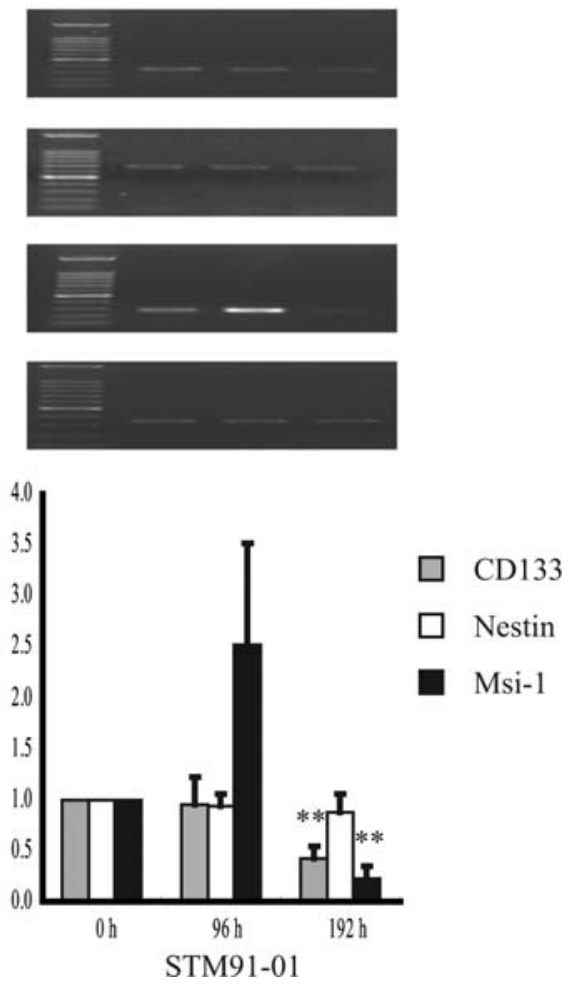

Figure 5. Competitive polymerase chain reaction (PCR) of cancer stem cell (CSC) markers before and after differentiation induction with N-(4-hydroxyphenyl) retinamid (4-HPR). (A) Nestin and Musashi-1 (Msi-1) mRNA expression was down-regulated in a time-dependent manner after differentiation induction with $3 \mu \mathrm{M} 4-\mathrm{HPR} .{ }^{* *} \mathrm{P}<0.005$, relative expression of nestin and Msi-1 mRNA on 0 vs. $48 \mathrm{~h}$ treated with $3 \mu \mathrm{M} 4-\mathrm{HPR}$. (B) Msi-1 mRNA expression in YAM-RTK-1 has slightly decreased after differentiation induction with $3 \mu \mathrm{M} 4-\mathrm{HPR}$. * $\mathrm{P}<0.05$, relative expression of Msi- $1 \mathrm{mRNA}$ on 0 vs. $48 \mathrm{~h}$ treated with $3 \mu \mathrm{M} 4-\mathrm{HPR}$. (C) In STM91-01, Msi-1 mRNA expression was increased temporarily with the peak level at $96 \mathrm{~h}$ and decreased afterwards, while CD133 mRNA expression decreased gradually in a time-dependent manner and nestin mRNA expression had no obvious change. ${ }^{* *} \mathrm{P}<0.005$, relative expression of CD133 mRNA on 0 vs. $192 \mathrm{~h}$ treated with $3 \mu \mathrm{M}$ 4-HPR and relative expression of Msi-1 mRNA on 0 vs. 96 or $192 \mathrm{~h}$ treated with $3 \mu \mathrm{M} 4-\mathrm{HPR}$.

Western blotting before and after differentiation-induction with 4-HPR. Western blot analysis on CD133 demonstrated the presence of CD133 protein in TM87-16 and STM91-01, but CD133 protein could not be detected in TTC1240 (Fig. 6A). Western blot analysis of nestin and Msi-1 before differentiation-induction almost correlated with the RT-PCR 
A

CD133

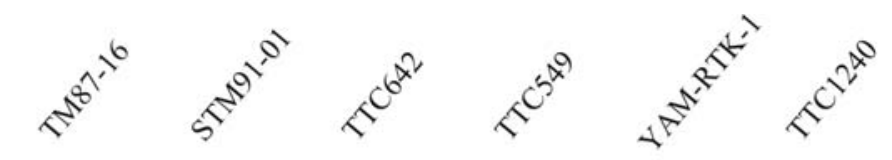

\section{$\mathrm{CD} 133$}

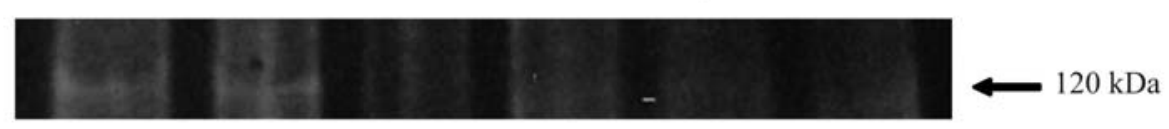

B

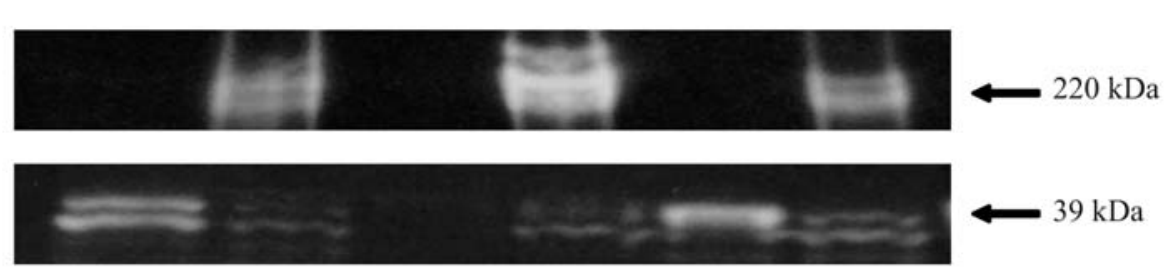

$\mathrm{D}$

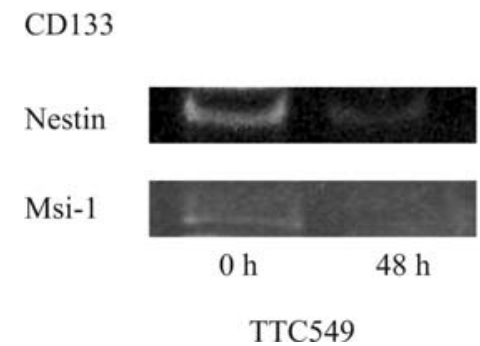

E

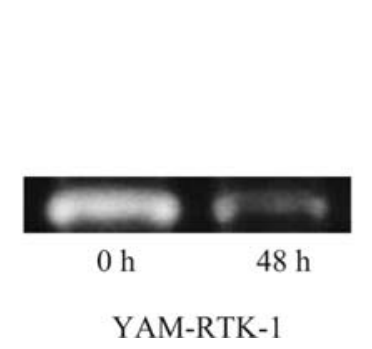

$\mathrm{F}$

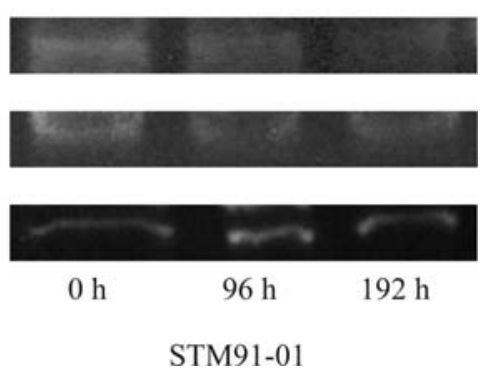

Figure 6. Western blotting before and after differentiation induction with N-(4-hydroxyphenyl) retinamid (4-HPR). (A) CD133 protein in TM87-16 and STM91-01 was detected, but CD133 protein could not be detected in TTC1240. (B) Nestin and (C) Musashi-1 (Msi-1) protein before differentiation induction with 4-HPR correlated with the RT-PCR findings. (D) In TTC549 after differentiation-induction with $3 \mu \mathrm{M} 4$-HPR, nestin and Msi-1 proteins were down-regulated such as the competitive PCR finding. (E and F) In YAM-RTK-1 and STM91-01, similar findings were recognized.

findings (Fig. 6B and C). In TTC549 after differentiation induction with $3 \mu \mathrm{M} 4-\mathrm{HPR}$, nestin and Msi-1 proteins were down-regulated as was the competitive PCR (Fig. 6D). Similar findings were recognized in YAM-RTK-1 and STM91-01 (Fig. 6E and F).

\section{Discussion}

MRT is commonly known for its highly aggressive biology and resistance to chemotherapy and radiation. The concept of the CSC arose from the observation of striking similarities between the self-renewal mechanism of stem cells and cancer cells $(22,23)$. Initially, this hypothesis was proven by the existence of a population of cells with the phenotype CD34 ${ }^{+}$CD38- in AML (33). Later, the presence of CSC was confirmed in neoplasms including brain tumors $(24,25)$, neuroblastoma (34), breast cancer (35), prostate cancer (36), colon cancer (37) and pancreatic cancer (38). MRT has been reported to have characteristics of multi-phenotypic diversity and some MRTs, in our previous research, demonstrated a neuroectodermal phenotype $(9,12)$. Herein we describe studies using human MRT cell lines suggesting they contain subpopulations of CSC which also have characteristics similar to NSC.

Cancers result from maturation arrest, resulting in continued proliferation of cells and a failure of cells to differentiate and die (39). Retinoids are well known to play a crucial role in cellular and tissue differentiation owing to their capability to activate and/or repress specific genes and consequently, to suppress tumor promotion and modify some properties of fully transformed malignant cells (40). Although 4-HPR is not considered to be toxic to normal mature cells (41), cell viability assay suggested that 4-HPR has an influence on cellular differentiation mechanisms of several MRT cell lines in vitro. The mechanism of action of 4-HPR is not yet completely understood, but it has been shown that 4-HPR may exert inhibitory effects by a receptor-dependent and nondependent manner (42-44). Binding of retinoids to the nuclearreceptors leads to the regulation of several cellular processes, including growth, differentiation and apoptosis (45). A unique feature of 4-HPR is its ability to inhibit cell growth and proliferation through the induction of apoptosis rather than differentiation. However, our results by light microscopy and apoptosis assay indicated that 4-HPR induces cell differentiation in MRT cell lines, but not apoptosis.

Before differentiation-induction with 4-HPR, NSC markers were expressed in various MRT cell lines. We considered that down-regulation of NSC markers such as CD133, nestin and Msi-1 by differentiation induction with 4-HPR indicates the possibility that these markers may exhibit characteristics of CSC as well as NSC.

CD133 a five-transmembrane domain glycoprotein originally found on hematopoietic stem and progenitor cells deriving from human fetal liver, bone marrow and cord blood $(46,47)$. The function of CD133 has not been established, but it may participate in the regulation of membrane topology 
(48). Recent data revealed that CD133 is highly expressed in CSC populations $(24,25,34-38)$ and high CD133 expression in STM91-01 was confirmed in our study. By the differentiation induction with 4-HPR, CD133 mRNA expression was gradually decreased. Although STM91-01 was established from a pulmonary metastasis of a renal MRT and the expression of CD133 is not limited to stem cells but observed in kidney proximal tubules (49), we hypothesized that CD133 expression in STM91-01 indicates the existence of an NSC population that may have characteristics of CSC.

Nestin is an intermediate filament protein typical for neural precursor cells and has been extensively used as a marker for NSC $(50,51)$. Nestin has been detected in brain tumors such as pilocytic astrocytomas and malignant gliomas including glioblastoma multiforme $(27,28,52,53)$. Our results showed that STM91-01, TTC549 and TTC1240 expressed nestin, which was detected by RT-PCR and Western blotting. These data support the possibility that these cell lines have an NSC phenotype. Moreover, in TTC549, the decrease in cell viability and down-regulation of nestin expression by differentiation induction with 4-HPR indicated that NSC in TTC549 may share the characteristics of CSC. In STM91-01, nestin was not down-regulated after differentiation induction with 4-HPR. It was reported that STM91-01 expressed megsin, which is a marker for mesangial cells (54). It was considered that nestin expression is also observed in podocytes of adult human kidney as well as stem cells (55).

Msi-1 is an RNA binding protein which is preferentially expressed in stem-cells, functions as a translational repressor (56-58), and is widely used as a molecular marker to identify stem cells in embryos and adult tissues (26-29). In our study, Msi-1 was expressed in five MRT cell lines except TTC642, which originated from a neck mass. These data also support the possibility that these cell lines have an NSC phenotype. After differentiation induction with 4-HPR, Msi-1 was downregulated or transiently up-regulated and then down-regulated. These phenomena indicate cellular differentiation in TTC549 and YAM-RTK-1 and or quite limited cellular differentiation in STM91-01. The significance of Msi-1 expression in MRT cell lines still remains unclear, but Msi-1 has been reported to be expressed in NSC, mostly in CNS or peripheral nervous system tumors. Like nestin, it was considered that MRT cell lines expressing Msi-1 may also show the characteristics of CSC.

Expression of NSC markers showed that some MRTs contain a subpopulation of NSC and down-regulation of NSC markers indicated that NSC in some MRTs may share characteristics with CSC. According to these results, expression of NSC markers in MRT cells provides supportive evidence that many MRTs are considered to be of neuroectodermal origin.

\section{Acknowledgements}

We thank Dr Hiroyuki Shimada and Dr Timothy J. Triche (Childrens Hospital Los Angeles, Los Angeles, CA, USA) for providing MRT cell lines. We also thank Mr. Masaki Suzaki, Mr. Takefumi Yamamoto, and Mr. Yasuhiro Mori (Central Research Laboratory, Shiga University of Medical Science) for their assistance. This study was partly supported by the Grant of Ministry of Education, No. 17209055.

\section{References}

1. Beckwith JB and Palmer NF: Histopathology and prognosis of Wilms' tumor: results from the first National Wilms' Tumor study. Cancer 41: 1937-1948, 1978

2. Biggs PJ, Garen PD, Powers JM and Garvin AJ: Malignant rhabdoid tumor of the central nervous system. Hum Pathol 18: 332-337, 1987.

3. Lynch HT, Shurin SB, Dahms BB, Izant RJ, Lynch J and Danes BS: Paravertebral malignant rhabdoid tumor in infancy: in vitro studies of a familial tumor. Cancer 52: 290-296, 1983.

4. Frierson HF, Mills SE and Inners DJ: Malignant rhabdoid tumor of the pelvis. Cancer 55: 1963-1967, 1985.

5. Hunt SJ and Anderson WD: Malignant rhabdoid tumor of the liver. A distinct clinicopathologic entity. Am J Clin Pathol 94: 645-648, 1990.

6. Gündüz K, Shields JA, Eagle RC Jr, Shields CL, De Potter P and Klombers L: Malignant rhabdoid tumor of the orbit. Arch Ophthalmol 116: 243-246, 1998.

7. Banzai C, Yahata T, Sasahara J, Kashima K, Fujita K, Nishikura K, Ajioka Y, Motoyama T and Tanaka K: Advanced malignant rhabdoid tumor of the ovary effectively responding to chemotherapy: a case report and review of the literature. Gynecol Oncol 105: 261-265, 2007

8. Haas JE, Palmer NF, Weinberg AG and Beckwith JB: Ultrastructure of malignant rhabdoid tumor of the kidney: a distinctive renal tumor of children. Hum Pathol 12: 646-657, 1981.

9. Ota S, Crabbe DCG, Tran TN, Triche TJ and Shimada H: Malignant rhabdoid tumor: a study with two established cell lines. Cancer 71: 2862-2872, 1993.

10. Rorke LB, Packer RJ and Biegel JA: Central nervous system atypical teratoid/rhabdoid tumors of infancy and childhood: definition of an entity. J Neurosurg 85: 56-65, 1996.

11. Packer RJ, Biegel JA, Blaney S, Finlay J, Geyer JR, Heideman R, Hilden J, Janss AJ, Kun L, Vezina G, Rorke LB and Smith M: Atypical teratoid/rhabdoid tumor of the central nervous system: report on workshop. J Pediatr Hematol Oncol 24: 337-342, 2002.

12. Suzuki A, Ota S and Shimada M: Gene expression of malignant rhabdoid tumor cell lines by reverse transcriptase-polymerase chain reaction. Diagn Mol Pathol 6: 326-332, 1998.

13. Higashino K, Narita T, Taga T, Ohta S and Takeuchi $Y$ : Malignant rhabdoid tumor shows a unique neural differentiation as distinct from neuroblastoma. Cancer Sci 94: 37-42, 2003.

14. Yoshida S, Narita T, Taga T, Ohta S and Takeuchi Y: Malignant rhabdoid tumor shows incomplete neural characteristics as revealed by expression of SNARE complex. J Neurosci Res 69: 642-652, 2002.

15. Bonnin JM, Rubinstein LJ, Palmer NF and Beckwith JB: The association of embryonal tumors originating in the kidney and in the brain. A report of seven cases. Cancer 54: 2137-2146, 1984.

16. Parham DM, Peiper SC, Robicheaux G, Ribeiro RC and Douglass EC: Malignant rhabdoid tumor of the liver. Evidence for epithelial differentiation. Arch Pathol Lab Med 112: 61-64, 1988.

17. Gonzalez-Crussi F, Goldschmidt RA, Hsueh W and Trujillo YP: Infantile sarcoma with intracytoplasmic filamentous inclusions: distinctive tumor of possible histiocytic origin. Cancer 49: 2365-2375, 1982.

18. Sugimoto T, Hosoi H, Horii Y, Ishida H, Mine H, Takahashi K, Abe T, Ohta S and Sawada T: Malignant rhabdoid-tumor cell line showing neural and smooth-muscle-cell phenotypes. Int J Cancer 82: 678-686, 1999

19. Biegel JA: Molecular genetics of atypical teratoid/rhabdoid tumor. Neurosurg Focus 20: E11, 2006.

20. Biegel JA, Rorke LB, Packer RJ and Emanuel BS: Monosomy 22 in rhabdoid or atypical tumors of the brain. J Neurosurg 73: 710-714, 1990.

21. Biegel JA, Tan L, Zhang F, Wainwright L, Russo P and Rorke LB: Alterations of the hSNF5/INI1 gene in central nervous system atypical teratoid/rhabdoid tumors and renal and extrarenal rhabdoid tumors. Clin Cancer Res 8: 3461-3467, 2002.

22. Reya T, Morrison SJ, Clarke MF and Weissman IL: Stem cells, cancer, and cancer stem cells. Nature 414: 105-111, 2001.

23. Pardal R, Clarke MF and Morrison SJ: Applying the principles of stem-cell biology to cancer. Nat Rev Cancer 3: 895-902, 2003.

24. Singh SK, Clarke ID, Terasaki M, Bonn VE, Hawkins C, Squire J and Dirks PB: Identification of a cancer stem cell in human brain tumors. Cancer Res 63: 5821-5828, 2003. 
25. Hemmati HD, Nakano I, Lazareff JA, Masterman-Smith M, Geschwind DH, Bronner-Fraser M and Kornblum HI: Cancerous stem cells can arise from pediatric brain tumors. Proc Natl Acad Sci USA 100: 15178-15183, 2003.

26. Nakano A, Kanemura Y, Mori K, Kodama E, Yamamoto A, Sakamoto H, Nakamura Y, Okano H, Yamasaki M and Arita N: Expression of the Neural RNA-binding protein Musashi1 in pediatric brain tumors. Pediatr Neurosurg 43: 279-284, 2007.

27. Strojnik T, Røsland GV, Sakariassen PO, Kavalar R and Lah T: Neural stem cell markers, nestin and musashi proteins, in the progression of human glioma: correlation of nestin with prognosis of patient survival. Surg Neurol 68: 133-143, 2007.

28. Ma YH, Mentlein R, Knerlich F, Kruse ML, Mehdorn HM and Held-Feindt J: Expression of stem cell markers in human astrocytomas of different WHO grades. J Neurooncol 6: 1-45, 2008.

29. Sanchez-Diaz PC, Burton TL, Burns SC, Hung JY and Penalva LO: Musashi1 modulates cell proliferation genes in the medulloblastoma cell line Daoy. BMC Cancer 8: 280, 2008.

30. Kenel MF, Krayer JH, Merz EA and Pritchard JF: Teratogenicity of N-(4-hydroxyphenyl)-all-trans-retinamide in rats and rabbits. Teratog Carcinog Mutagen 8: 1-11, 1988.

31. Chen S, Samuel W, Fariss RN, Duncan T, Kutty RK and Wiggert B: Differentiation of human retinal pigment epithelial cells into neuronal phenotype by $\mathrm{N}$-(4-hydroxyphenyl)retinamide. J Neurochem 84: 972-981, 2003

32. Samuel W, Kutty RK, Nagineni S, Vijayasarathy C, Chandraratna RA and Wiggert B: N-(4-hydroxyphenyl) retinamide induces apoptosis in human retinal pigment epithelial cells: retinoic acid receptors regulate apoptosis, reactive oxygen species generation, and the expression of heme oxygenase- 1 and Gadd153. J Cell Physiol 209: 854-865, 2006.

33. Bonnet D and Dick JE: 'Human acute myeloid leukemia is organized as a hierarchy that originates from a primitive hematopoietic cell.' Nat Med 3: 730-737, 1997.

34. Hansford LM, McKee AE, Zhang L, George RE, Gerstle JT, Thorner PS, Smith KM, Look AT, Yeger H, Miller FD, Irwin MS, Thiele CJ and Kaplan DR: Neuroblastoma cells isolated from bone marrow metastases contain a naturally enriched tumorinitiating cell. Cancer Res 67: 11234-11243, 2007.

35. Al-Hajj M, Wicha MS and Benito-Hernandez A: Prospective identification of tumorigenic breast cancer cells. Proc Natl Acad Sci USA 100: 3983-3988, 2003.

36. Collins AT, Berry PA, Hyde C, Stower MJ and Maitland NJ: Prospective identification of tumorigenic prostate cancer stem cells. Cancer Res 65: 10946-10951, 2005.

37. Ricci-Vitiani L, Lombardi DG, Pilozzi E, Biffoni M, Todaro M, Peschle C and De Maria R: Identification and expansion of human colon-cancer-initiating cells. Nature 445: 111-115, 2007.

38. Li C, Heidt DG, Dalerba P, Burant CF, Zhang L, Adsay V Wicha M, Clarke MF and Simeone DM: Identification of pancreatic cancer stem cells. Cancer Res 67: 1030-1037, 2007.

39. Sell S: Cancer stem cells and differentiation therapy. Tumour Biol 27: 59-70, 2006

40. Chambon P: A decade of molecular biology of retinoic acid receptors. FASEB J 10: 940-954, 1996.

41. O'Donnell PH, Guo WX, Reynolds CP and Maurer BJ: N-(4hydroxyphenyl)retinamide increases ceramide and is cytotoxic to acute lymphoblastic leukemia cell lines, but not to nonmalignant lymphocytes. Leukemia 16: 902-910, 2002.

42. Sun SY, Li W, Yue P, Lippman SM, Hong WK and Lotan R: Mediation of N-(4-hydoxyphenyl)retinamide-induced apoptosis in human cancer cells by different mechanisms. Cancer Res 59: 2493-2498, 1999.
43. Sheikh MS, Shao ZM, Li XS, Ordonez JV, Conley BA, Wu S, Dawson MI, Han QX, Chao WR, Quick T, Niles RM and Fontana JA: N-(4-hydroxyphenyl)retinamide (4-HPR)-mediated biological actions involve retinoid receptor-independent pathways in human breast carcinoma. Carcinogenesis 16: 24772486,1995

44. Fanjul AN, Delia D, Pierotti MA, Rideout D, Yu JQ and Pfahl Ml: 4-Hydroxyphenyl retinamide is a highly selective activator of retinoid receptors. J Biol Chem 271: 22441-22446, 1996.

45. Simeone AM and Tari AM: How retinoids regulate breast cancer cell proliferation and apoptosis. Cell Mol Life Sci 61: 1475-1484, 2004.

46. Yin AH, Miraglia S, Zanjani ED, Almeida-Porada G, Ogawa M, Leary AG, Olweus J, Kearney J and Buck DW: AC133, a novel marker for human hematopoietic stem and progenitor cells. Blood 90: 5002-5012, 1997

47. Miraglia S, Godfrey W, Yin AH, Atkins K, Warnke R, Holden JT, Bray RA, Waller EK and Buck DW: A novel five-transmembrane hematopoietic stem cell antigen: isolation, characterization, and molecular cloning. Blood 90: 5013-5021, 1997.

48. Shmelkov SV, St Clair R, Lyden D and Rafii S: AC133/ CD133/Prominin-1. Int J Biochem Cell Biol 37: 715-719, 2005.

49. Weigmann A, Corbeil D, Hellwig A and Huttner WB: Prominin, a novel microvilli-specific polytopic membrane protein of the apical surface of epithelial cells, is targeted to plasmalemmal protrusions of non-epithelial cells. Proc Natl Acad Sci USA 94: 12425-12430, 1997.

50. Cattaneo E and McKay R: Proliferation and differentiation of neuronal stem cells regulated by nerve growth factor. Nature 347 : 762-765, 1990.

51. Lendahl U, Zimmerman LB and McKay RD: CNS stem cells express a new class of intermediate filament protein. Cell 60: 585-595, 1990.

52. Dahlstrand J, Collins VP and Lendahl U: Expression of the class VI intermediate filament nestin in human central nervous system tumors. Cancer Res 52: 5334-5341, 1992.

53. Almqvist PM, Mah R, Lendahl U, Jacobsson B and Hendson G: Immunohistochemical detection of nestin in pediatric brain tumors. J Histochem Cytochem 50: 147-158, 2002.

54. Kato H, Ohta S, Koshida S, Narita T, Taga T, Takeuchi Y and Sugita K: Expression of pericyte, mesangium and muscle markers in malignant rhabdoid tumor cell lines: differentiation-induction using 5-azacytidine. Cancer Sci 94: 1059-1065, 2003.

55. Su W, Chen J, Yang H, You L, Xu L, Wang X, Li R, Gao L, $\mathrm{Gu}$ Y, Lin S, Xu H, Breyer MD and Hao CM: Expression of nestin in the podocytes of normal and diseased human kidneys. Am J Physiol Regul Integr Comp Physiol 292: R1761-R1767, 2007.

56. Sakakibara S, Imai T, Hamaguchi K, Okabe M, Aruga J, Nakajima K, Yasutomi D, Nagata T, Kurihara Y, Uesugi S, Miyata T, Ogawa M, Mikoshiba K and Okano H: MouseMusashi-1, a neural RNA-binding protein highly enriched in the mammalian CNS stem cell. Dev Biol 176: 230-242, 1996.

57. Kaneko Y, Sakakibara S, Imai T, Suzuki A, Nakamura Y, Sawamoto K, Ogawa Y, Toyama Y, Miyata T and Okano H: Musashi1: an evolutionally conserved marker for CNS progenitor cells including neural stem cells. Dev Neurosci 22: 139-153, 2000.

58. Okano H, Kawahara H, Toriya M, Nakao K, Shibata S and Imai T: Function of RNA-binding protein Musashi-1 in stem cells. Exp Cell Res 306: 349-356, 2005. 